\title{
PENGGUNAAN MEDIA PUZZLE DENGAN MODEL PEMBELAJARAN PICTURE AND PICTURE UNTUK MENINGKATKAN KEMAMPUAN MENYUSUN KATA PADA TEMA KEGEMARANKU KELAS 1 UPT. SD NEGERI 17 SARUASO
}

\author{
MISDAR \\ misdar17@gmail.com
}

\begin{abstract}
Based on the results of research observations in class 1 UPT. SD Negeri 17 Saruaso, many students still do not know the letters of the alphabet. The lack of teachers in introducing letters and letterforms to students so that there are still students who cannot distinguish between letters $b$ and $d$ and $m$ and $w$. The formulation of the problems in this study are: (1) How are the activities of the teacher in increasing the ability to compose words using puzzle media and the picture and picture learning model for class 1 UPT. SD Negeri 17 Saruaso? (2) How is the student's activity in improving the ability to compose words using puzzle media and the learning model of class 1 UPT's picture and picture. SD Negeri 17 Saruaso? (3) How to increase the ability to compose words using puzzle media and the UPT class 1 class 1 picture and picture learning model. SD Negeri 17 Saruaso?. Therefore, we need a learning model that can increase teacher and student activity and student learning outcomes. This study aims to describe the activities of teachers and students during learning. This research is a classroom action research. The subjects in this study were class I UPT. SD Negeri 17 Saruaso, totaling 17 students. Data were collected through teacher activity observation sheets and student activity observation sheets and test question sheets. The data analysis technique uses percentages. Based on student activity in the first cycle there were 12 students who completed $70.59 \%$ while the second cycle there were 15 students who completed $88.24 \%$ so the second cycle had an increase. Judging from the average cycle I 74.12 and cycle II 83.5
\end{abstract}

Keywords: Picture and Picture Learning Puzzle Media, Ability to Compose Words.

Abstract: Berdasarkan hasil observasi penelitian di kelas 1 UPT. SD Negeri 17 Saruaso, banyak siswa yang masih belum bisa mengenal huruf abjad. Kurangnya guru dalam mengenalkan huruf dan bentuk huruf kepada siswa sehingga masih ada siswa yang belum bisa membedakan antara huruf $b$ dan $d$ dan $m$ dan $w$. Adapun rumusan masalah dalam penelitian ini adalah : (1) Bagaimana aktivitas guru dalam meningkatkan kemampuan menyusun kata dengan menggunakan media puzzle dan model pembelajaran picture and picture kelas 1 UPT. SD Negeri 17 Saruaso? (2) Bagaimana aktivitas siswa dalam meningkatkan kemampuan menyusun kata dengan menggunakan media puzzle dan model pembelajaran picture and picture kelas 1 UPT. SD Negeri 17 Saruaso? (3) Bagaimanakah peningkatan kemampuan menyusun kata dengan menggunakan media puzzle dan model pembelajaran picture and picture kelas 1 UPT. SD Negeri 17 Saruaso?. Oleh karena itu, dibutuhkan suatu model pembelajaran yang dapat meningkatkan aktivitas guru dan siswa serta hasil belajar siswa. Penelitian ini bertujuan untuk mendeskripsikan aktivitas guru dan siswa selama mengikuti pembelajaran. Penelitian ini adalah penelitian tindakan kelas. Subjek dalam penelitian ini adalah kelas I UPT. SD Negeri 17 Saruaso yang berjumlah 17 siswa. Data dikumpulkan melalui lembar observasi aktivitas guru dan lembar observasi aktivitas siswa serta lembar soal tes. Teknis analisis data menggunakan persentase. Berdasarkan aktivitas siswa pada siklus I ada 12 siswa yang tuntas 70,59\% sedangkan siklus II ada 15 siswa yang EISSN 2657-0289 Lembaga Penelitian dan Penerbitan Hasil Penelitian Ensiklopedia 15 
tuntas $88,24 \%$ jadi siklus II mengalami peningkatan. Dilihat dari rata-rata siklus I 74,12 dan siklus II 83,5

Kata kunci: Media Puzzle Pembelajaran Picture and Picture, Kemampuan Menyusun Kata.

\section{A. Pendahuluan}

Pendidikan adalah suatu proses pembentukan kepribadian manusia, yang memungkinkan tumbuh dan berkembangnya semua potensi dan sumber daya yang dimiliki oleh seseorang. Peranan pendidikan sangat penting untuk menghasilkan sumber daya manusia yang berkualitas. Tanpa pendidikan, manusia akan terbelakang dan sulit berkembang (Mulyasa: 2004 - 6) Pendidikan merupakan suatu usaha dari setiap warga negara untuk meningkatkan kecerdasan, kecakapan dan keterampilan. Untuk memperoleh hal tersebut faktor penentunya adalah guru atau tenaga pendidik. Guru selaku pendidik harus mampu mengupayakan agar proses belajar mengajarnya mengalami kemajuan dan perubahan. Media pembelajaran merupakan salah satu upaya peningkatan interaksi belajar mengajar, sehingga materi yang sulit tersebut dapat dipahami secara langsung oleh siswa. (Wina: 2004 - 6) Oleh sebab itu, penggunaan media dalam pembelajaran sebagai alat bantu mengajar yang turut mempengaruhi kondisi dan lingkungan belajar yang dirancang dan dibuat oleh guru akan menimbulkan kegairahan dalam belajar, memungkinkan interaksi yang lebih langsung antara anak didik dan objek belajar dan memungkinkan anak belajar sendiri-sendiri menurut kemampuan dan minatnya.

Media pembelajaran sangat berperan dalam proses pembelajaraan. Disamping itu media juga merupakan bahan ajar yang diperlukan pada siswa untuk memahami inti dari pembelajaran. Pemanfaatan media dalam pembelajaran dapat membangkitkan keinginan dan minat baru, meningkatkan motivasi dan merangsang kegiatan belajar, dan bahkan berpengaruh secara psikologis pada siswa. Media juga sangat berpengaruh dalam mengembangkan teknik yang digunakan oleh seorang guru. Selanjutnya mengamati perkembangan kognitif anak didik, yang berkaitan dengan perkembangan kognitif seperti baca tulis, mengenal angka, sains, konsep mengelompokkan, dan meningkatkan kreativitas. Kelima bidang pengembangan tersebut diberi stimulasi agar perkembangannya optimal sehingga anak akan mendapatkan ketrampilan hidupnya. Salah satu perkembangan kognitif di atas meningkatkan kreativitas sangatlah penting dalam kehidupan anak didik dan secara tidak langsung dapat meningkatkan prestasi belajar anak didik di tingkat pendidikan selanjutnya.

Dari penjelasan tersebut, dapat diketahui dengan jelas bahwamedia sangat berperan penting dalam menunjang proses belajar baca tulis siswa, media adalah alat bantu guru dalam kegiatan pembelajaran dan memudahkan siswa. dengan adanya media guru akan lebih mudah dalam melaksanakan proses pembelajaran dan mempengaruhi siswa dalam meningkatkan psikolgis anak dan bahan ajar yang diperlukan pada siswa untuk memahami inti dari pembelajaran. Perkembangan anak dalam mengenal huruf dapat dilihat ketika anak sudah dapat menyebutkan simbolsimbol huruf, dan anak sudah dapat mengelompokkan menyebut huruf depan dari sebuah benda atau sebaliknya. Berdasarkan observasi awal di UPT. SD Negeri 17 Saruaso kelas I, banyak siswa yang masih belum bisa mengenal huruf dengan baik. Kurang nya guru dalam mengenalkan huruf kepada siswa. Oleh karena itu penggunaan media yang baik sangat mempengaruhi siswa dalam meningkatkan 
menyusun kata. Sebagaimana yang diketahui media adalah alat bantu siswa dalam proses pembelajaran dimana media tersebut adalah pengenalan huruf alfabet.

Permasalah lain yang terjadi masih banyak siswa yang belum bisa membedakan anatara huruf e dan $\mathrm{f}$ atau $\mathrm{m}$ dan $\mathrm{w}$, masih banyak siswa yang masih salah dalam menyebutkan huruf. Siswa di kelas Ia ada 4 siswa yang diantaranya belum mengenal huruf dengan baik. Siswa yang tidak mengenal huruf ada 6 siswa dan 7 siswa yang sudah mengenal huruf dengan baik dan tepat. Puzzle huruf dalam proses penggunaannya sangat menarik anak karena anak belajar huruf melalui bentuk huruf yang menarik dan ukuran yang cukup besar. Hal ini dapat meningkatkan motivasi anak untuk mengenal bentuk huruf dan gambar pada puzzle huruf.

Pengenalan bentuk huruf kepada siswa melalui puzzle huruf dapat dilakukan dengan terlebih dahulu mengenalkan bentuk huruf lepas. Berdasarkan pemahaman siswa atas huruf yang lepas, guru dapat meningkatkan nya dengan membelajarkan anak dengan bentuk huruf tertentu. Sebelum siswa menyusun kata guru harus memperkenalkan terlebih dahulu vokal dan huruf konsonan. Huruf Vokal adalah bunyi ujaran akibat adanya udara yang keluar dari paru-paru tidak terkena hambatan atau halangan. Jumlah huruf vokal ada 5, yaitu a, i, u, e, dan o. Pengenalan huruf vokal ini dilakukan dengan memperkenalkan bentuk huruf tersebut di papan tulis atau dengan menunjukkan bentuk setiap huruf sehingga anak mengenal dan memahami bentuk huruf vokal dengan tepat. Huruf Konsonan adalah bunyi ujaran akibat adanya udara yang keluar dari paru-paru mendapatkan hambatan atau halangan. Jumlah huruf konsonan ada 26 buah, yaitu b, c, d, f, g, h, j, k, 1, m, n, p, q, r, s, t, v, $\mathrm{w}, \mathrm{x}, \mathrm{y}$, dan z. Pengenalan huruf vokal dan konsonan secara dini sangat diperlukan sebagai dasar bagi anak dalam mengenal huruf serta dapat membaca dengan lancar. (Hariyanto: 2009 - 2) Pengenalan huruf dan bentuk huruf kepada anak sangat diperlukan dan anak dapat membedakan haruf satu dan huruf lainnya seperti b dan d.

Untuk mendukung peningkatan kemampuan anak dalam menyusun kata guru dapat menggunakan media pembelajaran. Salah satu media pembelajaran yang dapat digunakan untuk menyusun kata kepada siswa adalah puzzle huruf. Puzzle huruf merupakan media yang dapat dibentuk menjadi huruf dan kata tertentu.Puzzle adalah suatu gambar yang di bagi menjadi potongan-potongan gambar yang bertujuan untuk mengasah daya fikir, melatih kesabaran dan membiasakan kemampuan berbagi. Selain itu, puzzle juga dapat disebut permainan edukatif karena tidak hanya untuk bermain tetapi juga mengasah otak dan melatih antar kecepatan pikiran dan tangan.

Berdasarkan pengertian diatas dapat disimpulkan bahwa media puzzle adalah salah satu gambar atau tulisan yang telah dipotong dalam beberapa potongan yang bertujuan untuk memudahkan anak untuk memahami dalam menyusun huruf sesuai dengan kata yang ingin disusun. Oleh karena itu, penggunaan media puzzle dalam pembelajaran dapat membantu siswa dalam memahami dan meningkatkan perhatian siswa terhadap isi materi yang diajarkan. Model pembelajaranpicture and picture merupakan model pembelajaran yang menggunakan media gambar dan dipasangkan atau diurutkan menjadi urutan yang sistematis, seperti menyusun gambar secara berurutan, menunjukkan gambar, memberikan keterangan pada gambar dan menjelaskan gambar sehingga siswa dapat menemukan konsep materi sendiri dengan membaca gambar.

Berdasarkan pengertian diatas dapat disimpulkan bahwa model pembelajaran picture and picture merupakan model dimana guru menggunakan alat bantu yang EISSN 2657-0289 Lembaga Penelitian dan Penerbitan Hasil Penelitian Ensiklopedia 
berupa gambar untuk menjelaskan sebuah materi pembelajaran atau memfasilitasi siswa untuk lebih aktif belajar. Dengan model pembelajaran ini dapat menarik perhatian siswa dan siswa juga bisa bermain sambil belajar dalam mengurutkan gambar atau huruf menjadi urutan yang logis sehingga pembelajaran ini menjadi bermakna. Kombinasi antara media puzzle dengan model pembelajaran picture and picture merupakan solusi yang dapat digunakan dalam pembelajaran menyusun kata. Dimana seorang siswa dilatih untuk menyebutkan huruf alfabet, setelah itu guru membacakan beberapa kata untuk disusun oleh siswa. Kombinasi antara media puzzle dengan model pembelajaran picture and picture ini adalah salah satu media dan model yang bertujuan untuk mengembangkan potensi peserta didik untuk melancarkan membaca. Selain itu, media dan model ini juga bertujuan untuk membantu peserta didik untuk mengenal huruf dalam menyusun kata.

Oleh karena itu, penulis tertarik untuk mengadakan penelitian tentang media puzzle didasari pada kemampuan mengenal huruf yang dimiliki oleh anak tersebut sesuai dengan apa yang ingin diteliti dan membuat peneliti merasa tertarik untuk melakukan penelitian, dimana diharapkan media puzzle dapat membantu anak.Adapun penelelitian ini berjudul: Penggunaan media puzzle dengan model pembelajaran picture and picture untuk meningkatkan kemampuan menyusun kata pada tema kegemaranku kelas I UPT. SD Negeri 17 Saruaso dengan harapan agar media ini banyak diminati oleh siswa dan akan membuat suasana belajar lebih menarik dan menyenangkan sehingga tujuan pembelajaran dapat tercapai dengan baik.

\section{B. Metodologi Penelitian}

Bentuk penelitian ini adalah Penelitian Tindakan Kelas (PTK). Penelitian tindakan kelas berkembang dari penelitian tindakan. Menuru Kemmis, Penelitian tindakan adalah suatu bentuk penelitian reflektif dan kolektif yang dilakukan oleh peneliti dalam situasi sosial untuk meningkatkan penalaran praktik sosial mereka. Sedangkan menurut Hasley, (Wina Sanjaya, 2009: 24) penelitian tindakan adalah intervensi dalam dunia nyata serta pemeriksaan terhadap pengaruh yang ditimbulkan dari intervensi tersebut. Dari beberapa definisi tersebut, maka ciri utama dari penelitian tindakan adalah adanya perlakuan tertentu untuk memperbaiki cara kerja dalam dunia nyata. Menurut Wina Sanjaya (2009: 27) Penelitian Tindakan Kelas adalah proses kegiatan yang dimulai dari menyadari masalah pembelajaran yang terjadi di dalam kelas. Penelitian ini dilaksanakan langsung oleh guru dengan melakukan kegiatan refleksi diri pada awal dan akhir permbelajaran. Ia dilakukan untuk memecahkan masalah yang terjadi di dalam kelas dan harus dilakukan dalam keadaan yang sebenarnya dan tentunya tidak mengganggu program pembelajaran yang telah direncanakan sebelumnya. Penelitian tindakan kelas merupakan suatu pencermatan terhadap kegiatan belajar berupa sebuah tindakan yang sengaja dimunculkan dan terjadi dalam sebuah kelas secara bersama. Agar proses penelitian berjalan dengan baik, maka diperlukan suatu rancangan penelitian secara sistematis. Subjek penelitian ini adalah siswa kelas 1 UPT. SD Negeri 17 Saruaso Kecamatan Tanjung Emas Kabupaten Tanah Datar yang berjumlah 17 orang yang terdiri dari 7 orang perempuan dan 10 orang laki-laki. Penelitian ini dilaksanakan di kelas 1. Adapun yang diamati adalah keseluruhan proses dan hasil pelaksanaan pembelajaran pada siswa kelas 1 melalui penggunaan Media Puzzle dengan model pembelajaran picture and picture. Instrumen Penelitian adalah alat yang digunakan untuk mengumpul-kan data penelitian. Karena alat atau instrument ini mencerminkan juga cara 
pelaksanaannya, maka sering juga disebut sebagai teknik penelitian. Menurut Wina Sanjaya, (2009: 84) Penelitian sebagai suatu cara ilmiah dalam memecahkan masalah termasuk penelitian Tindakan Kelas. Penelitian memerlukan data-data empiris, dan data-data tersebut hanya akan diperoleh jika peneliti menggunakan instrumen atau teknik penelitian yang tepat. Dalam penulisan ini peneliti menggunakan instrumen penelitian berupa: 1) Lembar Observasi; dan 2) embar Soal. Adapun teknik pengumpulan data dalam penelitian ini adalah sebagai berikut: 1) Tes; 2) Teknik Observasi; dan 3) Dokumentasi

\section{Hasil Dan Pembahasan Deskripsi Kondisi Awal}

Data awal hasil belajar kemampuan menyusun kata pada tema kegemaranku melalui tes pratindakan (pre test), dari 17 siswa yang mengikuti pre test menunjukan hasil dibawah ini:

Tabel Hasil Belajar Kemampuan Menyusun Kata Pra Siklus

\begin{tabular}{|c|c|c|c|c|c|}
\hline \multirow[b]{2}{*}{ No } & \multirow[b]{2}{*}{ Nama Peserta Didik } & \multirow[b]{2}{*}{ KKM } & \multirow[b]{2}{*}{ Nilai } & \multicolumn{2}{|c|}{ Ketuntasan } \\
\hline & & & & $\overline{Y a}$ & Tidak \\
\hline 1 & Radja & 75 & 40 & & $\sqrt{ }$ \\
\hline 2 & Agiva Nayla & 75 & 40 & & $\sqrt{ }$ \\
\hline 3 & Danil Junaka & 75 & 80 & $\sqrt{ }$ & \\
\hline 4 & Daaliyah Harda Ningsih & 75 & 80 & $\sqrt{ }$ & \\
\hline 5 & Famela Azizah & 75 & 60 & & $\sqrt{ }$ \\
\hline 6 & Jihan Latixa Hanum & 75 & 80 & $\sqrt{ }$ & \\
\hline 7 & Karunia Febriani & 75 & 80 & $\sqrt{ }$ & \\
\hline 8 & Kasih Putri Delima & 75 & 60 & & $\sqrt{ }$ \\
\hline 9 & Listheya Serina & 75 & 100 & $\sqrt{ }$ & \\
\hline 10 & M. Afgan Hamizan & 75 & 60 & & $\sqrt{ }$ \\
\hline 11 & M. Alfarasyi & 75 & 80 & $\sqrt{ }$ & \\
\hline 12 & Nurul Syartika & 75 & 60 & & $\sqrt{ }$ \\
\hline 13 & Nadhira Humaira & 75 & 80 & $\sqrt{ }$ & \\
\hline 14 & Novi Apriani & 75 & 40 & & $\sqrt{ }$ \\
\hline 15 & Raki Almajid & 75 & 60 & & $\sqrt{ }$ \\
\hline 16 & Varis Laksmana & 75 & 80 & $\sqrt{ }$ & \\
\hline 17 & Andika & 75 & 40 & & $\sqrt{ }$ \\
\hline \multicolumn{2}{|c|}{ Jumlah } & & 1120 & 8 & 9 \\
\hline \multicolumn{2}{|c|}{ Nilai rata-rata } & & 65,88 & & \\
\hline \multicolumn{3}{|c|}{ Presentase } & & $47,06 \%$ & $52,94 \%$ \\
\hline
\end{tabular}

Dari data tabel di atas, dapat dilihat nilai rata-rata kelas adalah 65,88 Siswa yang berhasil mencapai KKM atau mendapat nilai $\geq 75$ adalah 8 siswa $(47,06 \%)$ dan siswa yang belum berhasil mencapai KKM atau mendapatkan nilai $<75$ adalah 9 siswa ( $52,94 \%$ ). Berdasarkan hasil pre test maka peneliti dan observer (teman sejawat) sepakat melakukan perbaikan berupa penelitian tindakan kelas untuk meningkatkan hasil belajar siswa pada tema kegemaranku. Rencana perbaikan ini menggunakan media puzzle dengan model pembelajaran picture and picture, yang diharapkan dapat meningkatkan kemampuan menyusun kata dalam proses 
pembelajaran sehingga hasil belajar juga meningkat. Selain itu, dengan adanya penelitian tindakan kelas ini diharapkan siswa yang belum mencapai KKM dapat mencapai KKM di kemudian hari.

\section{Deskripsi Hasil Penelitian Siklus I}

Penelitian ini dilakukan pada UPT. SD Negeri 17 Saruaso di kelas I dengan menggunakan media puzzle dengan model pembelajaran picture and picture pada tema 2 Kegemaranku, subtema 1, pembelajaran 1, dan subtema 2, pembelajaran 2. Sesuai dengan tujuan pada penelitian ini, peneliti ingin melihat aktivitas guru, aktivitas siswa dan hasil belajar yang diperoleh siswa selama proses pembelajaran berlangsung menggunakan media puzzle dengan model pembelajaran picture and picture. Setelah berlagsungnya pembelajaran pada RPP siklus I, guru memberikan tes dengan jumlah 5 soal yang diikuti oleh 17 siswa untuk mengetahui hasil belajar siswa, dan dengan ketuntasan minimal yang ditetapkan di UPT. SD Negeri 17 Saruaso minimal 75. Hasil tes belajar pada siklus I dapat dilihat pada tabel dibawah ini :

Tabel Daftar Nilai Tes Hasil Belajar Siswa pada Siklus I

\begin{tabular}{|c|c|c|c|c|c|}
\hline \multirow[b]{2}{*}{ No } & \multirow[b]{2}{*}{ Nama Peserta Didik } & \multirow[b]{2}{*}{ KKM } & \multirow[b]{2}{*}{ Nilai } & \multicolumn{2}{|c|}{ Ketuntasan } \\
\hline & & & & Ya & Tidak \\
\hline 1 & Radja & 75 & 40 & & $\sqrt{ }$ \\
\hline 2 & Agiya Nayla & 75 & 40 & & $\sqrt{ }$ \\
\hline 3 & Danil Junaka & 75 & 80 & $\sqrt{ }$ & \\
\hline 4 & Daaliyah Harda Ningsih & 75 & 100 & $\sqrt{ }$ & \\
\hline 5 & Famela Azizah & 75 & 80 & $\sqrt{ }$ & \\
\hline 6 & Jihan Lativa Hanum & 75 & 80 & $\sqrt{ }$ & \\
\hline 7 & Karunia Febriani & 75 & 80 & $\sqrt{ }$ & \\
\hline 8 & Kasih Putri Delima & 75 & 80 & $\sqrt{ }$ & \\
\hline 9 & Listheva Serina & 75 & 100 & $\sqrt{ }$ & \\
\hline 10 & M. Afgan Hamizan. & 75 & 80 & $\sqrt{ }$ & \\
\hline 11 & M.Alfarasyi & 75 & 80 & $\sqrt{ }$ & \\
\hline 12 & Nurul Syartika & 75 & 60 & & $\sqrt{ }$ \\
\hline 13 & Nadhira Humaira & 75 & 80 & $\sqrt{ }$ & \\
\hline 14 & Novi Apriani & 75 & 60 & & $\sqrt{ }$ \\
\hline 15 & Raki Almaiid & 75 & 80 & $\sqrt{ }$ & \\
\hline 16 & Varis Laksmana & 75 & 80 & $\sqrt{ }$ & \\
\hline 17 & Andika & 75 & 60 & & $\sqrt{ }$ \\
\hline \multicolumn{2}{|c|}{ Jumlah } & & 1260 & 12 & 5 \\
\hline \multicolumn{2}{|c|}{ Nilai rata-rata } & & 74,12 & & \\
\hline \multicolumn{4}{|c|}{ Presentase } & $70,59 \%$ & $29,41 \%$ \\
\hline
\end{tabular}

Hasil tes belajar di atas menunjukkan jumlah siswa yang mencapai ketuntasan belajar secara individu sebanyak 12 orang atau 70,59\% sedangkan 5 orang atau $29,41 \%$ belum mencapai ketuntasan belajar. Rata-rata hasil belajar yang diperoleh siswa adalah 74,12 belum memenuhi KKM yang ditentukan oleh UPT. SD Negeri 17 Saruaso yaitu minimal 75. Oleh karena itu persentase ketuntasan belajar siswa masih 
di bawah 75\%, maka ketuntasan belajar siswa pada siklus I belum mencapai ketuntasan belajar klasikal serta dari segi hasil pelaksanaan tindakan belum bisa dikatakan berhasil.

\section{Deskripsi Hasil Penelitian Siklus II}

Setelah berlangsungnya pembelajaran pada RPP siklus II, guru (peneliti) memberikan tes dengan jumlah 5 soal esay yang diikuti oleh 17 siswa untuk mengetahui hasil belajar siswa, dan dengan ketuntasan minimal yang ditetapkan di UPT. SD Negeri 17 Saruaso minimal 75. Hasil tes belajar pada siklus II dapat dilihat pada tabel dibawah ini :

Tabel Daftar Nilai Tes Hasil Belajar Siswa pada Siklus II

\begin{tabular}{|c|c|c|c|c|c|}
\hline \multirow[b]{2}{*}{ No } & \multirow[b]{2}{*}{ Nama Peserta Didik } & \multirow[b]{2}{*}{ KKM } & \multirow[b]{2}{*}{ Nilai } & \multicolumn{2}{|c|}{ Ketuntasan } \\
\hline & & & & $\mathrm{Ya}$ & Tidak \\
\hline 1 & Radja & 75 & 60 & & $\sqrt{ }$ \\
\hline 2 & Agiya Nayla & 75 & 60 & & $\sqrt{ }$ \\
\hline 3 & Danil Junaka & 75 & 80 & $\sqrt{ }$ & \\
\hline 4 & Daaliyah Harda Ningsih & 75 & 100 & $\sqrt{ }$ & \\
\hline 5 & Famela Azizah & 75 & 80 & $\sqrt{ }$ & \\
\hline 6 & Jihan Latiya Hanum & 75 & 80 & $\sqrt{ }$ & \\
\hline 7 & Karunia Febriani & 75 & 100 & $\sqrt{ }$ & \\
\hline 8 & Kasih Putri Delima & 75 & 80 & $\sqrt{ }$ & \\
\hline 9 & Listheya Serina & 75 & 100 & $\sqrt{ }$ & \\
\hline 10 & M. Afgan Hamizan & 75 & 80 & $\sqrt{ }$ & \\
\hline 11 & M. Alfarasyi & 75 & 80 & $\sqrt{ }$ & \\
\hline 12 & Nurul Syartika & 75 & 80 & $\sqrt{ }$ & \\
\hline 13 & Nadhira Humaira & 75 & 100 & $\sqrt{ }$ & \\
\hline 14 & Novi Apriani & 75 & 80 & $\sqrt{ }$ & \\
\hline 15 & Raki Almajid & 75 & 80 & $\sqrt{ }$ & \\
\hline 16 & Varis Laksmana & 75 & 100 & $\sqrt{ }$ & \\
\hline 17 & Andika & 75 & 80 & $\sqrt{ }$ & \\
\hline \multicolumn{2}{|c|}{ Jumlah } & & 1420 & 15 & 2 \\
\hline \multicolumn{2}{|c|}{ Nilai rata-rata } & & 83,53 & & \\
\hline \multicolumn{4}{|c|}{ Presentase } & $88,24 \%$ & $11,76 \%$ \\
\hline
\end{tabular}

Pada siklus II dapat dilihat bahwa sudah ada peningkatan pada hasil belajar siswa yaitu 15 siswa yang tuntas dalam belajar secara klasikal dengan nilai $88,24 \%$ dan 2 siswa yang tidak tuntas dengan nilai 11,76\%. Adapun rata-rata hasil belajar yang diperoleh siswa adalah 83,53 dan berada di atas nilai KKM yang ditetapkan oleh UPT. SD Negeri 17 Saruaso pada tema Kegemaranku. Berdasarkan hasil yang diperoleh dari siklus II dapat disimpulkan bahwa ketuntasan hasil belajar siswa pada pembelajaran menggunakan media puzzle dengan model pembelajaran picture and picture mengalami peningkatan.

\section{Pembahasan Hasil Penelitian}

Berdasarkan hasil penelitian di UPT. SD Negeri 17 Saruaso, Kecamatan Tanjung Emas Kabupaten Tanah Datar dengan melakukan penelitian terhadap kegiatan belajar mengajar dengan menggunakan lembar observasi guru dan siswa EISSN 2657-0289 Lembaga Penelitian dan Penerbitan Hasil Penelitian Ensiklopedia $\quad 21$ 
serta memberikan LKPD dan soal tes akhir yang berbentuk Esay dengan jumlah lima soal menyusun kata siklus I dan II pada siswa kelas I di UPT. SD Negeri 17 Saruaso. Kecamatan Tanjung Emas Kabupaten Tanah Datar. Proses pembelajaran dilakukan selama dua kali pertemuan

Analisis Aktivitas Guru. Guru yang mengelola pembelajaran dengan menggunakan media puzzle dengan modelpembelajaran picture and picture dalam penelitian ini adalah peneliti sendiri, sedangkan yang jadi pengamat adalah guru wali kelas I UPT. SD Negeri 17 Saruaso. Berdasarkan data yang dikumpulkan menunjukkan bahwa kemampuan guru dalam mengelola pembelajaran mengalami peningkatan. Sesuai dengan kemampuan guru pada setiap siklus bahwa kemampuan guru memperoleh rata-rata dari pengamat siklus I adalah 69,56\% (baik), dan siklus II 91,30\% (sangat baik). Dimana guru dinilai oleh guru bidang studi Bahasa indonesia melalui lembar observasi kemampuan guru dalam mengelola pembelajaran saat berlangsungnya proses pembelajaran. Hasil observasi tersebut dijadikan tolak ukur guru untuk mempertahankan yang sudah sangat baik dan meningkatkan pada aspek yang dianggap baik Evaluasi pembelajaran merupakan suatu proses untuk menentukan manfaat dan peningkatan dari kegiatan pembelajaran melalui kegiatan penilaian. Jadi, berdasarkan hal demikian maka kemampuan guru akan meningkat dengan memperbaiki kekurangan-kekurangan dari evaluasi pembelajaran.jika semua langkah pembelajaran yang dilaksanakan oleh guru telah sesuai dengan lembar observasi maka pembelajaran menggunakan media puzzle dengan model pembelajaran picture and picture akan mengalami peningkatan pada setiap siklus pembelajaran.

Analisis Aktivitas Siswa. Berdasarkan hasil pengamatan yang dilakukan oleh observer terhadap aktivitas siswa selama proses pembelajaran mengalami peningkatan sebagaimana yang terdapat pada tabel 4.3 dan 4.7. Pada siklus I aktifitas siswa masih kurang aktif yaitu pada pengerjaan LKPD serta masih kurang kerjasama di dalam kerja kelompok serta kurang berani dalam bertanya, akan tetapi aktivitas siswa mengalami perubahan pada siklus II siswa telah aktif dalam kerja kelompok serta telah bekerja sama dalam kerja kelompoknya.

Peningkatan Hasil Belajar Siswa. Untuk melihat peningkatan hasil belajar siswa dengan menggunakan media puzzledengan model pembelajaran picture and picture pada tema kegemaranku, maka peneliti mengadakan tes setelah pembelajaran selesai dilakukan. Tes yang diberikan bertujuan untuk mengetahui peningkatan hasil belajar dan kemampuan belajar siswa dalam memahami materi. Hasil analisis hasil belajar siswa melalui model pembelajaran picture and picture denganmedia puzzle menunjukkan adanya peningkatan ketuntasan belajar siswa untuk setiap siklusnya. Hal ini dari rata-rata hasil belajar siswa pada masing-masing siklus yakni pada siklus I (tabel 4.4) dengan nilai rata-rata 74,12. Dan pada siklus II (tabel 4.8) nilai rata-ratanya 83,53 . Hal ini membuktikan ketuntasan belajar siswa mengalami peningkatan dan lebih baik untuk setiap siklusnya. Tercapainya keberhasilan belajar ini tidak terlepas dari usaha guru dalam memotivasi untuk setiap kali pertemuan. Berdasarkan paparan di atas menunjukkan bahwa adanya peningkatan rata-rata tingkat ketuntasan belajar siswa melalui penggunaan media puzzle dengan model pembelajaran picture and picture yang diterapkan pada kelas I UPT. SD Negeri 17 Saruaso. 


\section{Penutup}

Berdasarkan hasil penelitian yang telah dilakukan, maka dapat diperoleh kesimpulan yaitu: 1) Aktivitas guru dalam meningkatkan menyusun kata dengan menggunakan media puzzle dan model pembelajaran picture and picture, pada siklus satu 69,56\% dan suklus II 91,30\%, dimana terjadi peningkatan yang baik antara siklus I dan II, guru melakukan perubahan dalam pembelajaran. Sehingga dapat menambah wawasan dan pengetahuan guru; 2) Aktivitas siswa dalam meningkatkan kemampuan menyusun kata dengan menggunakan media Puzzle dengan model pembelajaran picture and picturedidapati siklus I 73,80\% dan siklus dua 94,05\% dengan demikian adanya meningkatan antara siklus I dan II yang artinya siswa tidak bosan dalam mengikuti pembelajar dan menambah minat siswa dalam belajar sehingga membuat siswa tidak bosan dalam mengikuti proses belajar mengajar; 3) Media Puzzle dengan model pembelajaran picture and picture menyusun kata menunjukkan adanya peningkatan ketuntasan belajar siswa untuk setiap siklusnya. Hal ini dari rata-rata hasil belajar siswa pada masing-masing siklus yakni pada siklus I dengan nilai rata-rata 74,12. Dan pada siklus II nilai rata-ratanya 83,53

\section{Daftar Pustaka}

Anas, Sudijono. 2013. Evaluasi Pendidikan, Jakarta: PT Raja Grafindo Persada.

A. Suciaty al-Azizy. 2010. Asah ketajaman Otak Anak Plus Melejitkan Daya Ingatnya,Jogjakarta: Diva Press.

E Mulyasa. 2004. Implementasi Kurikulum, Bandung : PT Remaja Rosda Karya.

Ernawati. 2016 Penggunaan Media Pembelejaran Crowssword Puzzle Untuk Meningkatkan Keterampilan Berfikir Kreatif Siswa.

Fathurrohman, M. (2010). Model-model pembelajaran Inovatif. Jogjakarta: Ar-Ruzz Media

Hamdani. (2010). Strategi Belajar Mengajar. Bandung: Pustaka Setia

Istarani. 2011. Pembelajaran Inovatif (Refrensi Guru dalam Menentukan Model Pembelajaran). Medan: Media Persada

Munawir, Yusuf.2005. Pendidikan bagi anak dengan problema belajar, Jakarta: Direktorat jenderal pendidikan.

Nisak,Raisatun 2011.Lebih dari 50 Gama Kreatif Untuk Aktivitas Belajar .Jogjakarta:Diva Press

Suharsimi Arikunto, dkk. 2008..Penelitian Tindakan Kelas, Jakarta : PT Bumi aksara.

Suyatno.2004. Teknik Pembelajaran Bahasa dan Sastra.Surabaya: SIC.

Trianto. (2013). Mendesain Model Pembelajaran Inovatif, Progresif, Konsep, Landasan, dan Implementasinya Pada Kurikulum Tingkat Satuan Pendidikan (KTSP). Jakarta: Kencana Prenada Media Group.

Wina, Sanjaya.2004. Perencanaan dan Desain Sistem Pembelajaran, Prenada Media Group

Wina, Sanjaya. 2009.Penelitian Tindakan Kelas, Jakarta: Prenada Media Group. 